\title{
The Radical Ideas of Mary Wollstonecraft
}

\section{Susan Ferguson}

Ryerson University

digital.library.ryerson.ca/object/253

Please Cite:

Ferguson, S. (1999). The radical ideas of Mary Wollstonecraft. Canadian Journal of Political Science, 32(3), 427-450.

$\underline{\text { doi: } 10.1017 / \mathrm{S} 0008423900013913}$

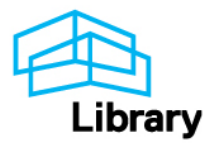




\title{
The Radical Ideas of Mary Wollstonecraft
}

\author{
SUSAN FERGUSON Ryerson Polytechnic University
}

\section{Introduction}

According to the standard narrative of feminist intellectual history, modern feminism in the English-speaking world begins with Mary Wollstonecraft's bold appeals for women's inclusion in a public life overwhelmingly dominated by men. Specific attention is drawn to her theories of character-formation and the importance of public education for women in nurturing the female faculty for reason. ${ }^{1}$ More recent scholarship, however, suggests this portrait of Wollstonecraft is unduly narrow, since it inspires a somewhat facile categorization of the first modern feminist as a liberal reformer and thus fails to elucidate the breadth of her social vision and the extent to which her ideas threatened to destabilize the ruling elite in late-eighteenth-century Britain.

Rooting their analyses in a wide range of Wollstonecraft's writings, feminist scholars now maintain a greater sensitivity to the historical and biographical context informing her work. As a result, a richer, more nuanced portrait of this early feminist emerges, one that convincingly attributes to her ideas a spirit of radicalism - that is, a commitment to push beyond the limited legislative reforms traditionally associated with the label "liberal feminism."

1 Between 1951 and the early 1970s, many of the commentaries on Wollstonecraft's life noted her participation in the movement for radical democracy but stressed her reformist aspirations, ignoring her radical socio-economic critique. See, for example, Ralph M. Wardle, Mary Wollstonecraft: A Critical Biography (Lawrence: University of Kansas Press, 1951); G. R. Stirling Taylor, Mary Wollstonecraft: A Study in Economics and Romance (1911; New York: Haskell House, 1969); H. R. James, Mary Wollstonecraft: A Sketch (New York: Haskell House, 1971); and Edna Nixon, Mary Wollstonecraft: Her Life and Times (London: Dent, 1971).

2 See, for example, Barbara Taylor, Eve and the New Jerusalem (London: Virago, 1983); Elissa Guralnick, "Radical Politics in Mary Wollstonecraft's A Vindication of the Rights of Woman," in Mary Wollstonecraft, A Vindication of the Rights of Woman, edited by Carol Poston (2d ed.; New York: W. W. Norton, 1988), 308-16; and Virginia Muller, "What Can Liberals Learn from Mary Woll-

Susan Ferguson, 8 Howie Ave., Toronto, Ontario M4M $2 J 1$.

Canadian Journal of Political Science / Revue canadienne de science politique XXXII:3 (September/septembre 1999) 427-50

(C) 1999 Canadian Political Science Association (l'Association canadienne de science politique) and/et la Société québécoise de science politique 
These revised accounts generally attribute Wollstonecraft's radical spirit to her recognition and condemnation of the pervading economic and social inequities of her day. In linking the project of women's emancipation to a broader socio-economic critique, they suggest, Wollstonecraft politicizes two institutions central to liberal theory: class and family. In the process, she not only distinguishes herself from others within the classical liberal tradition but also challenges the very separation of public and private spheres around which that tradition is constructed. For some, this feature of Wollstonecraft's thought is evidence of the radical potential that liberalism holds for feminism; for others it opens the door to subverting the liberal paradigm altogether. In fact, historian Barbara Taylor considers Wollstonecraft's treatment of class and family to be evidence of a socialist subtext, and credits her with paving the way for the emergence of the utopian brand of socialist feminism some 30 years later. ${ }^{3}$

Efforts to draw attention to Wollstonecraft's rebelliousness and the distance between her ideas and classical liberalism are long overdue, and prove a valuable point of departure for discussions of lateeighteenth-century feminism. But, in their enthusiasm to highlight the potential subversiveness of Wollstonecraft's feminism, many scholars have lapsed into an uncritical celebration of the possibilities of that feminism. As a result, some have attributed to Wollstonecraft political commitments she did not hold while obscuring the limits of the feminist ideals she did promote.

This article assesses Wollstonecraft's politicization of family and class through an exploration of her (incipient) critique of political economy. That critique, I suggest, rests squarely on what is, essentially, a liberal socio-economic model: the free-market activities of independent commodity producers (or, in Marxist terminology, a model of petty-bourgeois economic competition). ${ }^{4}$ This model is predicated

stonecraft?" and Wendy Gunther-Canada, "Mary Wollstonecraft's 'Wild Wish': Confounding Sex in the Discourse on Political Rights," in Maria J. Falco, ed., Feminist Interpretations of Mary Wollstonecraft (University Park: The Pennsylvania State University Press, 1996) 47-60; 61-84, respectively.

3 Taylor, Eve and the New Jerusalem, 5-6. Admittedly, the proto-socialist position on Wollstonecraft represents a relatively thin current of feminist thought, but it is a current that has passed without challenge. Nor are its representatives insignificant: Barbara Taylor, for example, is widely accepted as the authority on nineteenth-century socialist feminism. As well, it can be argued, casting Wollstonecraft's work in this light reinforces a more pervasive claim that the demand for women's equality is, in itself, always and everywhere destabilizing - a position articulated early on by Zillah Eisenstein (The Radical Future of Liberal Feminism [New York: Longman, 1981]) but evident in more recent scholarship. See, for example, Pamela Grande Jensen, ed., Finding a New Feminism: Rethinking the Woman Question for Liberal Democracy (Lanham: Rowman \& Littlefield, 1996).

4 For a discussion of the "petty-bourgeois" model and its centrality for both Classical Political Economy and early critics of that tradition, see David McNally, Against the Market (London: Verso, 1993). 
Abstract. Recent scholarship on Mary Wollstonecraft portrays her as either a liberal who disrupts the boundaries between public and private spheres or as a proto-socialist paving the road for a class-based feminism. Neither of these characterizations adequately captures the radical quality of her work. A close study of her views on class and family place her squarely within the liberal tradition of political economy. While she politicizes these institutions and, in so doing represents a threat to the latenineteenth-century British ruling classes, she neither disrupts the basic tenets of liberalism nor seriously anticipates the class insights of socialist feminism.

Résumé. Les études récentes consacrées à Mary Wollstonecraft la décrivent, soit comme une critique des thèses libérales sur la séparation des sphères privée et publique, soit comme une proto-socialiste ayant posé les jalons d'un féminisme de classe. Or ni l'une ni l'autre de ces conceptions ne rend compte adéquatement de la véritable signification de son oeuvre. Une analyse plus approfondie de ses idées sur les classes sociales et la famille démontre que ces dernières appartiennent clairement à la tradition de l'économie politique libérale. Bien que cette auteure ait mis en lumière la dimension politique de ces institutions, ce qui constituait en tant que tel un discours inquiétant pour les classes dirigeantes britanniques de la fin du $19^{\mathrm{e}}$ siècle, elle $\mathrm{n}$ 'a, ni remis en cause les principes fondamentaux du libéralisme, ni discerné le caractère de classe du féminisme socialiste.

on the sanctity of private property and a concomitant naturalization of the distinction between private and public realms. While welcoming the general point that Wollstonecraft is no mere liberal in the classical sense, I propose two qualifications to the more recent interpretations of her radicalism. First, Wollstonecraft's critique of class and familythough trenchant and politically explosive in her day - stops short of challenging the centrality of these institutions to liberalism; second, the relationship between Wollstonecraft's feminism and the feminism of the utopian socialists 20 years after her death is marked as much by rupture as by continuity. To develop these points we need, first, to clarify a few essential terms.

\section{Property, Family and Society: Liberal and Socialist Views ${ }^{5}$}

Classical liberalism developed in response to the quintessentially capitalist era differentiation of economic power from political power. That is, economic power came increasingly to depend upon private property and its utilization in the market, not on public title and office. ${ }^{6}$ Classical liberalism sought to explain and justify an economic sphere composed

5 The discussion that follows is necessarily, if regrettably, brief. I have tried to elucidate the key distinctions between socialism and liberalism, as they apply to the issues I raise around Wollstonecraft's politics. For more in-depth analysis, see Stuart Hall, "The State in Question" and David Held, "Central Perspectives on the Modern State" in Gregor McLennan, David Held and Stuart Hall, eds., The Idea of the Modern State (Philadelphia: Open University Press, 1984) 1-28; 29-79, respectively.

6 See Ellen Meiksins Wood, "The Separation of the 'Economic' and the 'Political' in Capitalism," New Left Review 127 (1981), 66-95. 
of (competitive) individual property owners who were also male heads of households. It begins by defining the economy and family as unchanging universal features of human life; these are, in other words, natural spheres. The activities each encompasses are treated as selfregulating, with the economy operating in accordance to the laws of competition based on private property and the family adhering to the moral-social code of patriarchal authority. Individual freedom is expressed in and through these economic and familial relations, or civil society. That freedom, however, needs to be protected - the task of a third institution, the state. Early liberal theory thus presents the state as the guarantor of rights and liberties appropriate to ownership and exchange. Whereas the state is a public authority, freedom can only be guaranteed, from the liberal point of view, if the essentially private nature of the economy and the family is respected. ${ }^{7}$

Two distinguishing features of classical liberal thought can be highlighted. First, liberalism is premised on the distinction between public and private realms of activities. In fact, the liberal project of emancipation depends entirely on maintaining the optimal balance between the two; whatever the nature of the interaction, without both sides of the equation there can be no freedom. The second defining feature of classical liberalism flows from the first: because the family and the economy are private and self-regulating, the social relations (of gender, class and race) that comprise these institutions are either ignored or are presumed to be manifestations of individual preference or ability. As such, they may be subject to a moral critique, but any challenge to inequality in the private sphere that fails to respect and preserve the private, self-regulating, nature of these relations is essentially illiberal.

On the other hand, classical socialism as it developed in the nineteenth century rejects both the privatization and naturalization of the family and the economy. ${ }^{8}$ It points instead to the essentially historical nature of each set of social relations, and in so doing uncovers the inequality on which each is premised. That is, family and economy are conditioned by, and representative of, changing social relations which develop, in turn, according to the ongoing conflicts and compromises of class forces. Rather than expressions of natural laws, class, gender

7 See C. B. MacPherson, The Political Theory of Possessive Individualism: Hobbes to Locke (London: Oxford University Press, 1962). As critics of liberalism have convincingly argued, the state is also instrumental in reinforcing the structure and relations of the family (see Carole Pateman, The Sexual Contract [Stanford: Stanford University Press, 1988]).

8 Classical socialism here refers to the nineteenth-century utopian and scientific socialists. See George Lichtheim, The Origins of Socialism (London: Weidenfeld and Nicolson, 1968). 
and race relations (and their inequalities) broadly express the socioeconomic interests of the dominant class of property owners. The state, far from being the neutral protector of freedom, works to reproduce the conditions of that domination. In historicizing the economy and family in this way, classical socialism challenges the liberal thesis of selfregulation, ${ }^{9}$ thereby rejecting the notion that the private sphere is free, or even fully distinct, from the public sphere. The very dichotomy of state and civil society on which liberal thought is based must be transcended if the socialist definition of emancipation is to prevail. And this can only occur if the basis of that distinction in private property and class exploitation is transcended as well.

\section{Where Does Wollstonecraft Fit In?}

Situating Wollstonecraft within the movement for radical democracy at the end of the nineteenth century, Barbara Taylor, Virginia Muller and others point to the political economic critique that underwrote that movement. As with her contemporaries, they suggest, at the heart of Wollstonecraft's egalitarian social vision stands a hostility to the dominant forms of property. In fact, some contend, she pushes beyond the limits of her contemporaries' political radicalism by extending that critique to the family. Wollstonecraft is portrayed in these accounts either as a liberal who disrupts the public/private dichotomy (and thereby proves the elasticity and, some argue, the inherently subversive potential of the liberal paradigm); or, as a sort of proto-socialist-a postliberal who incorporates aspects of socialism into her work and ultimately bridges the two paradigms. ${ }^{10}$

Neither of these characterizations, however, accurately captures the essence of Wollstonecraft's radicalism. While attributing the subversive quality of her work to her critique of political economy, current accounts offer surprisingly little detailed exploration of that critique. In taking a closer look at Wollstonecraft's economic views, I place particular emphasis on the ways in which she qualifies her hostility to prop-

9 Not all feminists agree that socialism offers a critical analysis of the family. Many reject it as inherently hostile to women's interests-more of an obstacle than an avenue to liberation. Others, however, criticize socialists for incorporating sexist assumptions and ignoring the issue of women's oppression, but remain convinced that the basic principles and methodology developed within socialism have a great deal to offer women. These feminists have done ground-breaking work on analyzing women's oppression from a socialist perspective in a nonreductionist manner, and have immeasurably enriched the socialist tradition. See, for example, the work of Dorothy Smith, Pat and Hugh Armstrong, Stephanie Coontz and Himani Bannerji.

10 Taylor, Eve and the New Jerusalem, 5-7, 17; Muller, "What Can Liberals Learn?" 49, 55-56; and Gunther-Canada, "The Same Subject Continued," 21112. 
erty. Her target is not property in general but aristocratic forms of property. She in fact endorses moderately sized private holdings (along with the class divisions underwriting these). This advocacy of private property and class reflects the economic and social priorities of competitive independent commodity producers, the social class at the heart of the classical liberal economic model.

But Wollstonecraft's liberalism is not "merely" economic. The competitive, capitalist economy has historically rested on a particular configuration of domestic relations: a nuclear household headed by a male breadwinner and managed by a female caretaker in the dual roles of wife and mother. ${ }^{11}$ It is precisely this domestic structure that informs Wollstonecraft's work. Rather than politicizing class and family in a way that challenges the separation of public and private spheres, her programme for female emancipation assumes these institutions are necessary, good and, indeed, natural. Her naturalization of the family leads her to argue, despite an openness to women's economic independence, that freedom is fundamentally about middle-class women fulfilling their duties as wives and mothers. And, against those who claim she speaks for and to all women, I suggest that Wollstonecraft's feminism is in fact class-based; her naturalization of class leaves her no strategy for the emancipation of working-class women. Despite egalitarian sentiments, Wollstonecraft ends up advocating the very oppressive conditions working-class women must struggle against. The class limits of such an approach are most clearly grasped when her views are compared to those of a near-contemporary, the earlynineteenth-century utopian socialist, William Thompson. Thus, in economic and social relations, this early feminist remains firmly within the liberal tradition. Her radicalism is based neither in a peculiarly socialist critique of political economy nor in any disruption of the public/private dichotomy on which liberalism rests. ${ }^{12}$

11 The literature on the historical and theoretical relationship between nuclear households and capitalism is vast. While early articles were often marred by an uncritical functionalism, more recent work is better attuned to the contradictory nature of social processes. Still, the most convincing accounts of this relationship are historical; even if capitalism does not, strictly speaking, require a nuclear household and sexual division of labour, such domestic relations only developed with the beginning of capitalism. Many of the seminal articles on households and capitalism are reproduced in Rosemary Hennessy and Chrys Ingraham, eds., $\mathrm{Ma}$ terialist Feminism: A Reader in Class, Difference, and Women's Lives (New York: Routledge, 1997). For an excellent historical account see Bonnie J. Fox, "The Feminist Challenge: A Reconsideration of Social Inequality and Economic Development," in Robert J. Prym and Bonnie J. Fox, eds., From Culture to Power: The Sociology of English Canada (Toronto: Oxford University Press, 1989), 120-77.

12 I am not suggesting Wollstonecraft does not politicize both class and family, but simply that she politicizes them by way of a moral critique. However significant 
While I position Wollstonecraft squarely within the liberal paradigm, I am not merely reasserting the standard account of her work. Indeed, I am challenging overly rigid readings of liberalism, though from a different perspective than those I criticize. Wollstonecraft does have strong ties to paradigmatically liberal views on the issues of family and political economy; but such positions can, and do, co-exist with a certain kind of radicalism. That radicalism is based neither in a peculiarly (proto-)socialist economic critique, nor in a potential to collapse the distinction between public and private spheres; it is based in what I will term a social radicalism - a radical politics that disrupts status quo notions of governance and authority. The political economic critique of aristocratic property forms is an important element of this radicalism as it pushes liberalism toward the logical limits of its premises. But it does so in a period politically unripe for such a logic - unripe because the liberal ruling class (the bourgeoisie), although economically powerful, has not yet gained political ascendancy over the old ruling class, the aristocracy. It is radical to call for equality of property and women's education in a period when these demands would, if granted, seriously upset the ruling classes' hold on power. ${ }^{13}$ Far from seeing Wollstonecraft as a "mere liberal," I affirm the radical scope of her social critique, but argue that her radicalism is best understood historically, as part of a liberal-democratic politics of resistance in late-eighteenthcentury Britain.

\section{A Radical Democratic Feminism}

The British radical reformers in the 1790s, with whom Wollstonecraft associated, were broadly grouped around the republican ideals articulated in Thomas Paine's Rights of Man. They blamed the arbitrary and disproportionate political power of the aristocratic few for the misery and poverty of the many. Men (and some included women in this designation) were rational and deserved to be ruled by reason rather than might. They were thus entitled by natural right to equal political representation. If only the corrupt institutions of aristocratic privilege could be swept away, human nature's potential for perfection could be realized.

Corresponding to this political analysis was an economic critique that shunned excessive wealth and the inheritance rules of primogeni-

a development within liberalism, her critique does not challenge the structural division between public and private spheres on which liberalism depends.

13 Barbara Taylor hints at this meaning of radicalism in arguing that the utopian vision of a world free of all oppression runs up against the reformist limits of bourgeois democracy (Eve and the New Jerusalem, 95-96). For an informed discussion of the nature of ruling-class power in the 1790s, see E. P. Thompson, The Making of the English Working Class (London: Penguin, 1963); and Roger Wells, Insurrection: The British Experience 1795-1803 (Gloucester: Alan Sutton, 1983). 
ture. Aristocratic privileges, Paine and others insisted, stood in the way of a family-based economy of artisans and farmers with relatively equal holdings of private property. In other words, they presumed an economic model of independent commodity producers which, despite its implied attack on the existing political and economic elite, was largely consistent with the premises of Adam Smith's Wealth of Nations. ${ }^{14}$

Because Wollstonecraft lived and worked alongside Paineite radicals, she was far removed from the respectable circles of bourgeois life - a fact used to advantage by her detractors. Published in the heated aftermath of the French Revolution, A Vindication of the Rights of Woman was identified by political and religious counter-revolutionaries as a Jacobin document, and Wollstonecraft's "degenerate" lifestyle (her first daughter was illegitimate and her second was born only a few months after she married William Godwin) was proclaimed proof of the dangerous implications of its arguments. "Viewed through the smoke of the Bastille," writes Barbara Taylor, "Wollstonecraft loomed like a blood-stained Amazon, the high priestess of 'loose-tongued Liberty.' "15

Although its contents offended middle-class sensibility, it is precisely with the middle layer of society - those women in the "most natural of states" - that Wollstonecraft is concerned, depicting them in what, at first glance, appears to be a surprisingly harsh light. ${ }^{16}$ In their current state, writes Wollstonecraft, women are weak and artificial: "Taught from their infancy that beauty is a woman's sceptre, the mind shapes itself to the body, and, roaming round its gilt cage, only seeks to adorn its prison." 17 They are ignorant of virtue and largely incapable of fulfilling their duties as mothers and wives with any degree of competence: they either neglect or spoil their children while their frivolity causes husbands to look elsewhere for companionship. Although Woll-

14 E. P. Thompson provides a wonderful social history of radical politics in the 1790s in Making of the English Working Class. For an insightful account of the links between popular political economy and the tradition of bourgeois political economy, see McNally, Against the Market, 43-61.

15 Taylor, Eve and the New Jerusalem, 11. According to R. M. Janes, A Vindication of the Rights of Woman initially passed largely unnoticed. It was not until Wollstonecraft's lifestyle was made public (with the appearance of Godwin's Memoirs in 1798) and the reaction against the French Revolution was in full swing that the book and its author were subjected to such vehement denunciation (R. M. Janes, "On the Reception of Mary Wollstonecraft's A Vindication of the Rights of Woman," Journal of the History of Ideas 39 [1978], 293-302). For other accounts of $A$ Vindication of the Rights of Woman's reception see Wardle, Mary Wollstonecraft, 158-60; Hal Draper, "James Morrison and Working-Class Feminism," in Hal Draper, ed., Socialism from Below (Atlantic Highlands, N.J.: Humanities Press, 1992), 226-27.

16 Wollstonecraft, Vindication, 9. Hereafter, the word "women" will refer specifically to middle-class women. References to women from other social classes will be made explicit.

17 Ibid., 44. 
stonecraft portrays the isolation of women's lives as oppressive, the dominant image she evokes speaks less of hardship and denial than it does of the (corrupting) privileges that result from the refined and pampered world women inhabit. Although women are in a state of "slavish dependence," she means only "in a political and civil sense; for, indirectly, they obtain too much power, and are debased by their exertions to obtain illicit sway."18

Yet, for Wollstonecraft, this scathing portrayal of women is not just moral patter. Her harsh words are not simply directed at women; they are meant more as a lever of social criticism and, in fact, indict a whole society. Like that of her radical contemporaries, Wollstonecraft's work is informed by a firm conviction that people are the products of their environment. Women are not predisposed to be petty and self-indulgent. These traits develop only because political and social forces deny them the expression and development of the defining feature of humanity: the capacity to reason.

Wollstonecraft's conviction that rationality is equally present in men and women is argued in part on theological grounds. Because all people owe their existence to a rational deity, they must share in the faculty of reason to an equal extent: "the nature of reason must be the same in all, if it be an emanation of divinity, the tie that connects the creature with the Creator." 19 Thus it follows that a just society is one based on reason. And the rational organization of relations on earth is nothing more than the unfolding of God's will:

I love man as my fellow; but his scepter, real, or usurped, extends not to me, unless the reason of an individual demands my homage; and even then the submission is to reason, and not to man. In fact, the conduct of an accountable being must be regulated by the operations of its own reason; or on what foundation rests the throne of God? ${ }^{20}$

Herein lies the fundamental contradiction of the political organization of society: it extends the rational sceptre to middle-class men but not to women. Men's civil superiority is, Wollstonecraft argues, nothing but the residue of an era marked by inequality and force. It is a vestige of that "pestiferous purple which renders the progress of civilization a

18 Ibid., 167. She consistently draws an analogy between women and the very wealthy - an important reminder of just how far from her mind the plight of working-class and peasant women often was. See, for instance, 7, 60, 57.

19 Ibid., 53. Without reason, Wollstonecraft argues, women would be animals (rather than persons or moral beings) who live by the rule of brute force. But, she states, "surely there can be but one rule of right, if morality has an eternal foundation." And that one rule is reason. Mankind, she writes, is to be guided by "a rational will that bows only to God" (36).

Ibid., 37. 
curse, and warps the understanding." ${ }^{21}$ Insisting that it is entirely inconsistent for men to fight against aristocratic privilege amongst themselves while maintaining similar distinctions with respect to their wives and daughters, she suggests the task is to eliminate the hypocrisy which denies women are fully human (rational beings) and to raise men and women to a level at which they are able to relate to each other as equals.

Wollstonecraft's programme for reform clearly places the emphasis on the self-development of the individual woman: "It is time to effect a revolution in female manners - time to restore to them their lost dignity - and make them, as a part of the human species, labour by reforming themselves to reform the world." 22 This requires that women be permitted to participate in all areas of political, economic and cultural life. And, as so much of the scholarship on Wollstonecraft emphasizes, the key to "reforming themselves" is education. Lamenting that the "grand source of misery [is] the neglected education of my fellow-creatures," she offers a detailed discussion of what an appropriate education for girls (and boys) should entail. ${ }^{23}$ These passages serve to reinforce the traditional view of Wollstonecraft as a bourgeois liberal campaigner for reform.

Any portrait of the first modern feminist that comes to rest here, however, is incomplete; for Wollstonecraft, issues of feminism do not simply revolve around the question of women's denied opportunity for education and their restricted access to civil society. Reform of the education system is impotent in face of the general lack of freedom which characterizes late-eighteenth-century Britain. "Till society be differently constituted," she insists, "much cannot be expected from education." ${ }^{24}$ Specifically, Wollstonecraft attacks the system of representation which excludes most men (in addition to all women) from the franchise. But her criticism is not limited to the constitution. Rather, she indicts the system of unequal representation for upholding damaging socio-economic arrangements - arrangements which work to perpetuate the inequality between the sexes. The British system of representation, she notes, is nothing less than "a convenient handle for despotism" which keeps the majority of humanity in the bondage of ignorance. ${ }^{25}$ It serves only to maintain the idle rich by taxing the poor. Without a total transformation of society in which people relate to each

21 Ibid., 18.

22 Ibid., 45; emphasis added.

23 Ibid., 7. For the discussion of education reform see 157-78.

24 Ibid., 21.

25 Ibid., 147. Interestingly, she does not outrightly advocate female suffrage, but only hints that it might not be as preposterous a proposal as she assumes her readership believes. 
other as equal partners (in politics and in all else), women's emancipation is impossible.

The egalitarian thrust of Wollstonecraft's work is not a frivolous addition, but an integral element of her feminism. Women simply cannot be free and rational in an irrational world. Elissa Guralnick is thus correct to stress that for the eighteenth-century feminist: "all will be right [only when the whole of] society has undergone a radical reordering. In the promise of that reordering lies the extreme political radicalism that is at once the premise and the sine qua non of $A$ Vindication of the Rights of Woman." 26

\section{The Radical Edge to Economic Liberalism}

It is certain that Wollstonecraft's attack on the broader political order distinguishes her feminism as a radical social critique. The nature of the threat it represents to the social order, however, is not clearly established. Guralnick and Taylor point to the fact that Wollstonecraft's socio-economic critique revolves around an attack on private property. But they both slide too easily from this observation to the claim that Wollstonecraft opposes fundamental features of capitalist social relations - a claim they back with assertions about the inclusiveness of her emancipatory project. Guralnick, for instance, writes that Wollstonecraft "closely associates the betterment of woman's plight with the rise of the classless society." And, referring readers to Wollstonecraft's plea for equality, she contends that the eighteenth-century feminist's vision of a rational society translates into a "total leveling of distinction among men (and women).'27

Taylor, for her part, agrees with this assessment and applauds Wollstonecraft for beginning to overcome "the narrow class assumptions on which so much of the radical tradition was based." She, too, suggests Wollstonecraft's programme was directed to "the social and political liberation of 'the people' as a whole," locating in her egalitarianism "the ideological roots of Socialist feminism." 28 It is not, Taylor believes, that Wollstonecraft consciously articulates a socialist perspective. Rather, its presence in A Vindication of the Rights of Men is embryonic. Evidence for this kernel of socialist thought can be found not only in the threat to property represented by the demands of radical democracy, but also in Wollstonecraft's repudiation of commercial society and her condemnation of the inhumanity of industry's drive for profit. As well, Taylor highlights a passage from $A$ Vindication of the Rights of Men in which, she claims, Wollstonecraft puts forward "a 
proposal for a communalist society of small peasant-producers which could be established ... simply by expropriating all the large estates in Britain and redistributing the land across the entire population" 29 For Guralnick and Taylor, Wollstonecraft's radicalism has its roots in an economic critique of property which, if pursued politically, would emancipate women and men from class exploitation. By this reading, Wollstonecraft is indeed a proto-socialist, at least in political economic terms.

The hostility Wollstonecraft expresses toward certain forms of property cannot be denied. In A Vindication of the Rights of Men (her reply to Edmund Burke's Reflections on the Revolution in France ${ }^{30}$ ), she castigates those moderns who claim to speak for the rights of all but "bow down to rank, and are careful to secure property." Liberty has yet to be realized anywhere on the globe, she writes, because "the demon of property has ever been at hand to encroach on the sacred rights of men, and to fence round with awful pomp laws that war with justice." 31 Two years later she compares it to a poisoned fountain from which flows "most of the evils and vices which render this world such a dreary scene to the contemplative mind." 32 These are undeniably powerful indictments of the British system of property ownership and, viewed in isolation, could foster the belief that Wollstonecraft's goal is the elimination of private property and the economic leveling of all wealth. But this conclusion is not warranted within the context of Wollstonecraft's work as a whole. Rather than attacking class distinction and possibly setting the stage for a socialist politics of feminism, Wollstonecraft remains wedded to the basic framework of a liberal critique of political economy. As with her radical democratic associates, her ire is directed at the very rich, those who comprise the old authoritative order.

The specific plea for a return to equality and nature which Guralnick cites goes out, not to property owners in general, but specifically to "kings and nobles," to whom Wollstonecraft appeals to "throw off their gaudy hereditary trappings." The navy and the clergy come under attack alongside "the sacred majesty of kings" because within these professions men, who are themselves trained to a blind submission to

29 Ibid., 6-7; emphases added. The passage to which Taylor refers is found in Wollstonecraft, A Vindication of the Rights of Men . . . (2d ed.; London, 1790) reproduced in The Pickering Masters series, Janet Todd and Marilyn Butler, eds., The Works of Mary Wollstonecraft, Vol. 5 (London, 1989), 57, hereafter, Men. Taylor's interpretation is criticized below.

30 Edmund Burke, Reflections on the Revolution in France, edited and introduced by Conor Cruise O'Brien (Penguin: Harmondsworth, 1968).

31 Wollstonecraft, Men, 60, 9. To be clear, Wollstonecraft does not include Burke amongst the moderns she condemns. See also Moira Ferguson and Janet Todd, Mary Wollstonecraft (Boston: Twayne, 1984), 46.

32 Wollstonecraft, Vindication, 140. 
authority, wield power by virtue of the same irrational impulse. The main instrument of class distinction and social oppression is not property itself, but excessive wealth, perpetuated by the unequal system of inheritance. Thus Wollstonecraft's egalitarianism is not an argument for classlessness; rather, it is an indictment of precapitalist British social relations in which distinction is inherited rather than "earned." 33

But the critique of inheritance is less radical than might be expected: Wollstonecraft does not call for an end to inherited wealth, but for a reform in its practice and an end only to inherited honours. Property passed down the generations is objectionable only if it is tied to rules of primogeniture. Further, contrary to Taylor's suggestion, Wollstonecraft does not advocate the communalization of large estates but calls instead for their parcelization. The text reads: "Why cannot large estates be divided into small farms? these dwellings would indeed grace our land." ${ }^{34}$ Her vision here is of a certain form of private property - the moderate holdings of independent commodity producers. It is a form she also advocates in her discussion of enclosure; engaging in the essentially liberal discourse of improvement which originates with the agrarian concerns of seventeenth-century British liberalism, Wollstonecraft calls for the transformation of common land into individual private farms. ${ }^{35}$ The above passage continues:

Why are huge forests still allowed to stretch out with idle pomp and all the indolence of Eastern grandeur? Why does the brown waste meet the traveller's view, when men want work? But commons cannot be enclosed without acts of parliament to increase the property of the rich! Why might not the industrious peasant be allowed to steal a farm from the heath?

Unlike others in her day who responded to poverty and despair of the dispossessed by arguing for the preservation of common land, Wollstonecraft is more interested in establishing rights to private property. She argues for their consolidation in a particular, albeit relatively egalitarian, form. In other words, although she challenges the liberal rights claim to unlimited accumulation, Wollstonecraft does not advocate interference with the fundamental precondition of that claim-the right to private property. The proximity of her views to those of the classical liberal political economists is striking. While they did not go so far as

33 Ibid., 22; emphasis added; 17-18, 44, 140-41. Guralnick gives two references: Poston, ed., Vindication, 22, 38 or pages 38 and 74 of an unspecified early edition, marked London, 1792, of which I found two publications (a 1929 Everyman's Library edition and a 1970 Gregg International edition). Searching the second reference yields nothing that substantiates Guralnick's thesis.

34 Wollstonecraft, Men, 57.

35 The centrality of the "improvement discourse" to early liberal theory is ably discussed by Neal Wood in John Locke and Agrarian Capitalism (Berkeley: University of California Press, 1984), 15-30. 
to advocate an absolute equality of property, many (including Adam Smith) believed that the competitive system, by its own accord, would result in precisely the relative equality of condition Wollstonecraft endorses - that is, an economy of moderately prosperous independent producers. ${ }^{36}$

Moreover, Wollstonecraft supports this economic liberalism with corresponding social values. Her endorsement of improvement through enclosure has already been noted; she also embraces the quintessentially liberal notion of reward according to merit. Moira Ferguson and Janet Todd suggest Wollstonecraft's ideas are "potentially revolutionary," but they impute a peculiar meaning to this phrase - one that has little to do with a socialist critique of society. Rather, it refers to Wollstonecraft's desire to replace the current system not with classless or communal social relations, but with "a system based on individual talent and reason." 37 Wollstonecraft singles out royalty, the military and noblemen for criticism precisely on the basis that they hold no virtuous (rational) justification for their rank. Distinctions of rank corrupt, she holds, "because respectability is not attached to the discharge of the relative duties of life, but to the station." 38 That merit (measured in accordance with the performance of duties), rather than station, should be the basis of distinction is not a view that sits easily with the classical socialist concept of equality in which wealth is distributed according to need.

Thus, while it is indisputable that Wollstonecraft's criticism of the sacrosanctity of certain forms of property is sometimes bitter, she is not opposed to it in all its manifestations. Far from undermining rights to private property, like her radical contemporaries she assumes their presence and argues for their continuity on a relatively egalitarian basis - but an egalitarianism that is, in fact, limited to a certain class of people: property owners. The class basis of Wollstonecraft's economic model is confirmed and elaborated in her discussion of women's work, working-class women and freedom.

\section{Women's Work, Working-Class Women and Freedom}

Wollstonecraft describes the ideal situation as that in which the family is moderately wealthy, able to sustain itself in comfort (although not luxury) with some funds remaining for charitable allowances and the

36 This is the model Smith develops in the early chapters of Book I of The Wealth of Nations. Although this model was popularized in the political economy tradition, in later chapters Smith introduces a more complex model. On this point, see David McNally, Political Economy and the Rise of Capitalism: A Reinterpretation (Berkeley: University of California Press, 1988), 215-16.

37 Ferguson and Todd, Mary Wollstonecraft, 118.

38 Wollstonecraft, Vindication, 144. 
purchase of books. Women find fulfillment as wives and mothers and their education is primarily justified as a means to that fulfillment. Their husbands, who are also their best friends (passionate love is not, she believes, a stable basis for a relationship) and intellectual equals, arrive home from work to a clean and contented household. In fact, the scenario of domesticity Wollstonecraft paints is nothing short of idyllic. She reflects, "I have thought that a couple of this description, equally necessary and independent of each other, because each fulfilled the respective duties of their station, possessed all that life could give." 39

This vision is not very far removed from the life to which the middle classes actually aspired (which, according to Wollstonecraft, was simply a more frivolous version of the same basic structures and relations). And, like the period's middle-class households, Wollstonecraft's ideal rests squarely on a given class relation. Sustaining a household in a moderate degree of comfort, she claims, necessitates the employment of a female servant. For a woman to discharge "the duties of her station" she requires "merely a servant maid to take off her hands the servile part of the household business." 40 Women's emancipation, then, is utterly dependent upon the prior existence of a class of women whose labour power is available to perform the more menial and mundane household chores of the middle classes. It is emancipation of the few at the expense of the many.

More often than not, however, feminist scholars ignore or explain away this assumption of class exploitation in an effort to claim for Wollstonecraft a radical legacy. Zillah Eisenstein, for example, agrees Vindication does not directly address the needs of working-class women. Still, she claims, Wollstonecraft's egalitarianism extends to all and thereby successfully provides the conditions of emancipation for poor women, although she fails to explain how Wollstonecraft's appeal for equality overrides her assumption of an economic class of labourers. ${ }^{41}$

Indeed, in a period when most young women worked as domestic servants, Wollstonecraft offers comparatively little discussion of their plight. An important exception is her novel, The Wrongs of Woman, or Maria.$^{42}$ Here she portrays Jemima, a young servant woman, as lacking the escapes available to the middle-class Maria. Commenting on this novel, Ferguson and Todd write "the tale from beginning to end indicts society, as women's social conditioning, their social (lack of) possibili-

40 Ibid., 142. See also 66.

41 Eisenstein, The Radical Future of Liberal Feminism, 98.

42 Mary Wollstonecraft, The Wrongs of Woman, or Maria, in Gary Kelly, ed., Mary, A Fiction \& the Wrongs of Woman (London: Oxford University Press, 1976). 
ties, and the inability to work for a decent living reappear in a reformulation of the laboring class." 43 Ferguson and Todd do not suggest that the author harbours anything more than sympathy for the poor, pointing out that "she eschewed concrete proposals for the amelioration of [servants'] condition." ${ }^{44}$ Moreover, in Jemima's case, oppression is not resolved through economic independence, but through the heroism of individual strength of character. This, coupled with Wollstonecraft's attachment to the principle of reward for merit, suggests that Wollstonecraft may believe working-class women do not enjoy financial security because they have not earned it.

Her commitment to a class-divided society is reinforced in her comments on women's duties within the household and on education reform. On women's duties, Wollstonecraft writes, "To render the poor virtuous they must be employed, and women in the middle rank of life ... might employ them, whilst they themselves managed their families, instructed their children, and exercised their own minds." She lists gardening, experimental philosophy and literature as pursuits appropriate to the middle-class woman. ${ }^{45}$ And on education, although ahead of her day in advocating schooling for all members of society, her proposals are not free of class bias: children from all classes were to begin school at the age of five and pursue a common curriculum to age nine, at which point they are to be "streamed" according to class. Those from the middle class or, as Wollstonecraft calls them, "the young people of superior abilities, or fortune," would study academic subjects, while working-class children would learn the skills appropriate to their station. ${ }^{46}$ Feminists often overlook this important qualification to the democratizing of education, and thus exaggerate the degree to which Wollstonecraft stretches a more conventional liberal approach to education. Virginia Miller, for instance, writes, "Progress and education are linked, as for all liberal thinkers, but Wollstonecraft broadens their scope to insist that all citizens be educated. It is significant that she does not exclude the lower classes from this argument either." 47

43 Ferguson and Todd, Mary Wollstonecraft, 110.

44 Ibid., 122. They write: "In more general terms, Wollstonecraft seems to be saying that an individual, from whatever class, has an internal, events-motivated power that can bring about or at least allow for the possibility of personal, if not economic, autonomy" (111).

45 Wollstonecraft, Vindication, 75.

46 Ibid., 169. Wollstonecraft's willingness to advance those of superior abilities softens the naked class bias that underwrites her system to advance those of superior fortune regardless of ability - but only in a manner that is consistent with the liberal principles of merit.

47 Muller, "What Can Liberals Learn?" 53. 
I argue above that at the heart of Wollstonecraft's emancipatory project is the nuclear household. But how does she reconcile this commitment to the household with her insistence that women be allowed to use their education to gain economic independence? For Wollstonecraft, after all, it is essential to humanity and consistent with a rational society that women be permitted access to all the occupations. She advocates that they be allowed to work as physicians and nurses or midwives; to study politics and history; to enter into business relationships. ${ }^{48}$ These two prescriptions are at odds with one another, for how can a woman be both responsible for the domestic sphere and economically independent?

To what degree Wollstonecraft's individualism contradicts her assumption of traditional sex roles is a question that could feasibly be asked of all liberal theorists who preceded her and many of those who followed. Carole Pateman explores this issue specifically in the work of social contract theorists in The Sexual Contract. For these thinkers, the confrontation of the autonomous individual who enjoys rights and freedoms beyond the household with the assumption of household labour and child-rearing is resolved at the level of gender, where it becomes clear that the category "individual" is not intended for women at all. ${ }^{49}$ For Wollstonecraft, this conflict resides within the individual woman.

The standard resolution to this conflict is to invoke the liberal concept of equality of opportunity. Wollstonecraft, it is claimed, actually intends women to have the option to search for satisfying employment outside the home. And while she fails to explain how this can co-exist with their household duties, "presumably women who wanted to work would do so, and their participation and contribution would necessarily improve the level of civilized society." 50 But the equal opportunity Wollstonecraft endorses is not that simple. First, a whole class of women have been cut off from exercising the right to economic independence: the schooling she proposes for working-class women falls well short of that required to practise medicine or business. Second, Wollstonecraft stresses that although women should be given access to careers, she wants to ensure that access is exercised only by the very

48 Wollstonecraft, Vindication, 147-49.

49 Neither is it intended for working-class men, although Pateman suggests (I think unconvincingly) that they ultimately are implicated through a fraternity of male power.

50 Ferguson and Todd, Mary Wollstonecraft, 122. See also Wardle, Mary Wollstonecraft, 154; Gary Kelly, Revolutionary Feminism: The Mind and Career of Mary Wollstonecraft (London: Macmillan, 1992), 130; and Syndy McMillen Conger, Mary Wollstonecraft and the Language of Sensibility (Toronto: Associated University Press, 1994) 123. 
few. Women who work outside the home are likely to be single or at least childless, and of "exceptional talent." 51

Moreover, for the "equal opportunity" thesis to be convincing, the essence of female emancipation for Wollstonecraft would be found neither in motherhood nor careers, but in the opportunity for women to choose to live as they will. But this completely misses the moral thrust of Vindication. Wollstonecraft's understanding of liberty has little to do with the negative concept implied by the more modern liberal principle of equality of opportunity. Rather, she suggests, a free society must be a virtuous society. Freedom is a positive phenomenon corresponding with a specific code of ethics, which she believes emanates from a rational deity. The moral imperative to do one's duty is definitive of rationality and thus of freedom. Ralph Wardle observes that Wollstonecraft's feminism is informed by a strong sense of ethics: "to Mary politics was always subservient to religion.... Unlike most of her fellow radicals she was a devout believer, convinced that the perfection attainable in this world was not the ultimate toward which man should strive, but only a pale shadow of the perfection which God had reserved for him in heaven." 52

Women, in her view, should be granted equal opportunity, but not in order to do as they will. Equal opportunity must serve a greater end: "the only method of leading women to fulfill their peculiar duties, is to free them from all restraint by allowing them to participate in the inherent rights of mankind." 53 That is, while women should be free to be individuals in the so-called public sphere, they are most truly free when they are fulfilling their rational natures. And for all but the exceptional women, that nature (or "their peculiar duties") is found in their roles as wives and mothers: "I consider that women in the common walks of life are called to fulfil the duties of wives and mothers, by religion and reason, I cannot help lamenting that women of a superiour cast have not a road open by which they can pursue more extensive plans of usefulness and independence." 54 For the vast majority of middle-class

51 Wollstonecraft, Vindication, 64. The whole discussion linking work to economic independence is far removed from the reality of working-class women's lives. While plenty of women worked, female wages in the 1790 s were not sufficient to provide women with a meaningful level of independence - an issue Wollstonecraft does not consider.

52 Wardle, Mary Wollstonecraft, 164. See also Carolyn W. Korsmeyer, "Reason and Morals in the Early Feminist Movement: Mary Wollstonecraft," in Poston, ed., Vindication, 285-97.

53 Wollstonecraft, Vindication, 175; emphasis added.

54 Ibid., 146-47. She is, on this point, unequivocal: "whatever tends to incapacitate the maternal character, takes woman out of her sphere" (177). Wollstonecraft's suggestion that career woman would be "exceptional" is indicative of an elitist predisposition. Although all persons may be equally capable of great achievements, only a few, those of a "superiour cast," can and should fulfill that poten- 
women, then, motherhood informed by reason is and must be the essence of emancipation. This is not simply the most rational arrangement, it is also the most virtuous.

\section{The Public/Private Dichotomy in Wollstonecraft's Feminism}

A number of studies of Wollstonecraft suggest that her critique of the family is in fact a challenge to the very structures which define it as a private, self-regulating, institution. Guralnick, for instance, argues that the connection Wollstonecraft draws between the public and private spheres is inherently radical. She cites Wollstonecraft's analogy of the family and the state ("A man has been termed a microcosm; and every family might also be called a state") as well as her contention that the virtue of the public domain is largely dictated by that of the private as evidence that Wollstonecraft challenges the distinction between the two spheres. ${ }^{55}$ Dorothy McBride Stetson agrees: "Wollstonecraft had an organic view of the interdependence of all social institutions; separation of public and private spheres was artificial and the root of the sorry state of women in the aristocratic circles she observed." 56

The claim that Wollstonecraft challenges the structural distinction between public and private realms, however, is difficult to accept. She clearly politicizes the family insofar as she mounts a moral critique of the unequal gender relations therein. And because she attributes that inequality to the "irrational" organization of society at large, drawing a link between private and public realms, her moral critique leads to advocacy of structural change: increase women's access to education and careers, and establish a relative equality amongst property holders.

But this manner of politicizing the private realm does not, in itself, disrupt the structural separation of public and private spheres that is at the heart of liberalism. First, although she suggests the two spheres do not exist in isolation from each other, in her mind the relationship between them is not particularly problematic. She simply proposes that

tial. Beneath people's apparently equal natures, then, dwells a critical variation in abilities which possibly explains not only the division within the middle class between career women and mothers, but also the division between working- and middle-class women. For her explicit statements on human nature, see 9-10, 23, 42, 51-57. The same elitist predisposition can be traced in John Stuart Mill's work as well. See Paul Smart, Mill and Marx: Individual Liberty and the Roads to Freedom (Manchester: Manchester University Press, 1991).

55 Guralnick, "Radical Politics," 314. She cites Wollstonecraft, Vindication, 177, 192.

56 Dorothy McBride Stetson, "Women's Rights and Human Rights: Intersection and Conflict," in Falco, ed., Feminist Interpretations, 172; emphases added. Similarly, Virginia Muller contends that it is the structure of the family and the institution of marriage that Wollstonecraft identifies as the "linchpins of women's problems" ("What Can Liberals Learn?" 55; emphasis added). 
they are mutually influential with one sphere mirroring the other. To be consistent, Guralnick, McBride Stetson and others would also have to argue that the sixteenth-century political theorist Jean Bodin, for one, shares this radical quality, since he posits exactly the same relation between household and state as Wollstonecraft.

Second, despite endorsing certain types of structural changes, Wollstonecraft sees no reason to blur the distinction between the household and civil society. In fact she argues for its consolidation by confirming a natural sexual division of labour. ${ }^{57} \mathrm{In}$ their reformed state, the household becomes the fundamental social unit, morally and economically, of the new society: the preservation of "private virtue" (by which she means a marriage between equals that accepts the traditional sexual division of labour) is "the only security of public freedom and universal happiness." 58 Her criticism of domestic arrangements, then, is limited to the effect marriage and the household have on women's character formation. As a result, the reforms she suggests are directed to improving the quality of the individuals within what is considered to be an essential and natural social unit. She would like women to be capable of moving more easily between the household and civil society, but without jeopardizing the sanctity of the former. It is, in fact, not at all clear that Wollstonecraft's ideal rational domestic sphere would be any more politicized or any less isolated from the economic realm, than the irrational sphere she wants it to replace.

In politicizing familial relations in this manner, Wollstonecraft undoubtedly pushes liberalism in a particular, arguably progressive, direction. And in drawing attention to the inequalities of gender, she highlights the fundamental contradiction of liberalism so aptly analyzed by Carole Pateman. But to suggest that she resolves (or points to a resolution of) that contradiction by challenging "the structure of the family and the institution of marriage" or that she "confronted and bridged" the public/private dichotomy is to misread her work and attribute to her a more radical position than she in fact held. ${ }^{59}$

For a glimpse at a feminist radicalism that can be traced to a challenge to all forms of private property and class, and to a structural critique of the public/private dichotomy, it is useful to turn to the work of William Thompson, a leading Owenite and one of the movement's most able proponents of women's equality. Thompson advocates more than a broad social equality of property holders. He demands the elimination of private property on which the system of individual competition is based. This vision of human liberation is informed by an ap-

57 Wollstonecraft, Vindication, 7, 150-52.

58 Ibid., 6.

59 Muller, "What Can Liberals Learn?" 55; emphases added; and McBride Stetson, "Women's Rights," 172. 
preciation for the implications of women's biology in relation to the critical appraisal of competition he outlines in his 1824 work, An Inquiry into the Principles of the Distribution of Wealth. .. ${ }^{60}$ The arena in which these economic and biological considerations intersect is the private household unit. And it is in their respective comments on the household that the fundamental incompatibility of Thompson's and Wollstonecraft's conceptions of female (and human) liberation is thrown most clearly into relief.

Thompson is highly critical of the inhumanity of the isolation women suffer within the household. He writes of the "state of barbarous exclusion of domestic imprisonment, in which women have been kept." Women are "cut off" from sources of knowledge and "confined" to a home which he describes as "the eternal prison-house of the wife." He calls their domestic labour "so wicked a project of isolation." 61 The scathing tenor of these comments is not diminished in his reflections on the legal institution at the base of the household-marriage. He vilifies the marriage code as "that disgrace of civilization." Marriage sets up a false contract, "all of whose enjoyments ... are on the one side, while all of its pains and privations are on the other!" 62 The contrast with Wollstonecraft is immediately apparent. Undeniably critical of domesticity under current arrangements, her moral and economic attachment to the household makes it highly improbable that she would have joined Thompson in this vitriolic condemnation of marriage and the private household unit.

Thompson extends his condemnation of the household to a critique of sexuality in which he stresses the sensuality of women as well as of men: "An adult human being, though a woman, and though a wife, is possessed of all the senses, the appetites, the faculties and capabilities of enjoyment, of any other adult human being." 63 In fact, Thompson sees the repression of women's sexuality (women, he writes, "cannot even murmur about neglect") as a fundamental social problem. ${ }^{64}$ Wollstonecraft, embracing the mind/body dualism that characterizes much liberal thought, eschews the bodily side of existence for the most part. It represents our commonality with all animals and is in direct opposition to our rational mental capacity which, because it is unique to humans, she designates as the essence of humanity and the fountainhead of morality. She associates sensuality

60 William Thompson, An Inquiry into the Principles of the Distribution of Wealth... (London: printed for Longman, Hurst, Rees, Orme, Brown and Green, Paternoster-Row; and Wheatly and Adlard, 1824).

61 William Thompson, Appeal of One-half the Human Race, Women ... , introduced by Richard Pankhurst (London: Virago, 1983), 122, 17, 79, 133.

62 Ibid., 56, xxx.

63 Ibid., 70; emphasis added.

64 Ibid., 78. 
with both the repressive and retrograde aristocracy and the "weak and common herd." It is a force to be overcome. The sensualist is "the most dangerous of tyrannts," and women have too long been its slaves. ${ }^{65}$

Wollstonecraft argues for women to aspire to a "decent personal reserve," a modesty based on knowledge rather than ignorance. The hierarchy of intellect over sensibility is most explicit in her remonstration against passionate love within marriage. She urges that "tumultuous passion" be restrained and not "allowed to dethrone superior powers." Her criticism of the forces which teach women as a matter of course to satisfy men sexually do not lead her to challenge the existing balance in sexual relations. The ideal is "the chaste wife, and serious mother" who "only consider[s] her power to please as the polish of her virtues." 66 Sexuality then must be subordinated to the rational order of relations which, as we have seen, finds its locus in the single family household unit.

But the most significant difference between Wollstonecraft and Thompson is that Thompson's moral critique is situated within a structural explanation of society that challenges both class rule and the public/private dichotomy. He attributes women's sexual repression to the prevailing system of marriage which is itself a result of competition. Because poverty forces women into marital relations with men, sexual enjoyment is, "just like every thing else in society, a matter of trade." 67 But he objects to the terms of the exchange. Women gain limited and imperfect security and are expected in return, among other things, to gratify their husband's sexual desire. Meanwhile the pursuit of sexual pleasure for themselves is hypocritically deemed a vice. Alternatively, in conditions of full security (in which private property has been communalized), economic necessity would no longer be determinant and men and women could engage in sexual enjoyment freely and by mutual assent. Furthermore, because they are each others' equals, the number of potential pairings is increased considerably - the attraction between individuals grows, he believes, as they become more alike. In

Wollstonecraft, Vindication, 52.

66 Ibid., 27-28. On the sublimation of the sensual in Wollstonecraft's writing see Cora Kaplan, "Wild Nights," in Cora Kaplan, ed., Sea Changes: Culture and Feminism (London: Verso, 1986); Diana Coole, Women in Political Theory (Boulder: Lynne Rienner, 1988). Jean Grimshaw disagrees ("Mary Wollstonecraft and the Tensions in Feminist Philosophy," in Sean Sayers and Peter Osborne, eds., Socialism, Feminism and Philosophy [London: Routledge, 1990], 9-26). Grimshaw insists that Wollstonecraft argues for a balance of rationality and female sexual pleasure. But the most textual evidence she can cite for this is that Wollstonecraft finds value, in her novel Maria, in the heroine's empathy and tenderness; emotions are not to be totally subordinated to reason.

67 Thompson, An Inquiry into the Principles, 556. See also 41, 61, 189. 
co-operative societies, sexual pleasure for both men and women, Thompson predicts, will multiply. ${ }^{68}$

Thompson challenges the traditional domestic unit and raises the possibility of different patterns of human relationships. Despite an assumed heterosexuality and an arguable predisposition for monogamy, he resists designing an ideal form of sexual relations. This is to be decided democratically by the community: "with the length, or terms, of the connexion we have nothing here to do; that matter falling under the head of general legislation." 69

Nonetheless, he does discuss how co-operation makes feasible certain arrangements that are either illegal or impractical under competitive conditions. Because the community as a whole cares for nursing women and children, divorce is an accessible alternative and there is no reason to deny either party the opportunity to remarry. Thompson is also confident that enlightened public opinion will prevail, removing the humiliation and illegitimacy of co-habitation and childbirth outside marriage. ${ }^{70}$ Addressing the issue of birth control, he suggests that "prudential foresight" or "manual and physical restraints and expedients" provide a means to increase sexual (as well as moral and intellectual) pleasure. ${ }^{71}$

Thus, "private" matters of marriage, childbirth and child-rearing and even sexual pleasure, are not presumed to be self-regulating. They are clearly circumscribed, in Thompson's view, by the structural conditions of a competitive market economy. And to improve upon them it is essential to reject the self-regulation thesis of liberalism and alter those structural conditions by challenging private property, class and the public/private divide in a way that Wollstonecraft would never have imagined possible or desirable.

\section{Conclusion}

Although Wollstonecraft does politicize class and family by advocating radical social re-organization as a precondition of women's emancipation and drawing attention to unequal gender relations within the family, she neither harbours a proto-socialist feminist politics nor a propensity to disrupt the essential distinction between private and public spheres inherent to the liberal tradition. These claims, however, do not

68 Thompson writes, "inasmuch as they would be stripped of all their grossness and associated with intellectual and expansive sympathetic pleasures" sexual pleasures would be increased one hundredfold"' (ibid., 300). Later in the book, he increases this estimate tenfold (558).

69 Ibid., 556.

70 Ibid., 157, 150.

71 William Thompson, Labor Rewarded: The Claims of Labor and Capital Conciliated . . (London: printed for Hunt and Clarke, 1827), 112; and Inquiry, 549. 
diminish the radical quality of her politics. Indeed, the viciousness with which the radical democratic movement was suppressed in the late 1790s (along with the fact that the repression was spearheaded by an economic liberal, William Pitt) is a telling indication of the extent to which such ideas posed, or were perceived to pose, a real threat to the existing order. ${ }^{72}$

Moreover, Wollstonecraft's radicalism is based in her politicization of class and family. But we have to be careful to explain the nature of that politicization. Wollstonecraft's economic and moral egalitarianism are radical insofar as they confront the sociohistoric limits of the ruling ideas of her day. It was radical to argue for women's essential rationality, their right to education and careers, and to tie those demands to an argument for a relative equality of property in a period when the dominant liberal ideas were heavily influenced by notions of aristocratic privilege and inherited honours. Such demands, like those of her fellow radical democrats, were beyond the historic possibilities imagined by a ruling class composed of those from bourgeois and aristocratic backgrounds.

But her radicalism did not threaten the very existence of class and family as institutions. The author of Vindication is unabashedly committed to the sanctity of private property, and it is this commitment that leads her to endorse the distinction between the private and public spheres as necessary and desirable. In other words, despite an inherent radicalism, Wollstonecraft's feminism is shaped by some of the most fundamental moral and economic principles of liberalism. One needs only to peruse the tracts of the Owenite socialists, written some 30 years later, to gain a sense of a feminist politics that develops out of a theoretical framework which rejects class, private property and a public/ private dichotomy.

72 This attack on the established order was predominantly posed in political, rather than economic, terms, with most of the radical democrats either ignoring questions of political economy or endorsing a "petty-bourgeois" model. This, however, in the context of aristocratic privilege and the aftermath of the French Revolution, was sufficient to unleash the full power of the state's repressive arm. That is, the radical democrats were vilified because the authorities feared political democracy would lead to economic leveling (see Wells, Insurrection). 